مقاله يخوهشى

مجله دانشگاه علوم يزشكى رفسنجان

Sوره 19. مهر

مدلسازى شيوع بيمارى آنفلوانزاى فوق حاد يرند كان در استان تيلان

با مدل هاى داده كاوى و سيستم اطلاعات مكانى در سال هوب إ: يكك مطالعه اكولوزيكى

سيد مسعود هاشمى فومنى '، حميد مطيعيان r

يذيرش مقاله: 99/0/11

دريافت اصلاحيه از نويسنده: 99/0/1

دريافت مقاله: 99/\%/19 ارسال مقاله به نويسنده جهت اصلاح: $99 / \varepsilon / \%$

جִكيده

زمينه و هدف: ابتلاء يرندگان به بيمارى آنفلوانزاى فوق حاد يرندگًان (Highly Pathogenic Avian Influenza) و از بين رفتن آنها خسارات سنگينى به صنعت دام و طيور و بهداشت عمومى كشور تحميل مى كند. امروزه با توجه به حجم و تنوع دادهها، ضرورت استفاده از فناورىهاى مكان محور و علوم دادهكاوى ضرورى به نظر مىرسد. هدف اين تحقيق مدلسازى شيوع بيمارى آنفلوانزا فوق حاد يرندكان به كمك قابليتهاى تحليل مكانى مىباشد.

مواد و روش ها: در يزوهش حاضر كه به صورت تحليلى-اكولوزيكى است، سال هوبا با ميزان بالاى شيوع اين بيمارى به عنوان سال تهيه متغيرهاى Vا Fانه (اقليمى، محيطى و انسان ساخت) و ايجاد لايههاى مكانى، در استان گيلان انتخاب گرديد. با استفاده از تلفيق تحليل رگرسيونى تقويت شده (Boosted Regression Trees; BRT) و رگرسيون وزندار جغرافيايى، وزنهاى Receiver Operating Characteristic; ) اين متغير ها محاسبه و مدل شيوع بيمارى تهيه و توسط منحنى عملياتى دريافت كننده (ROC

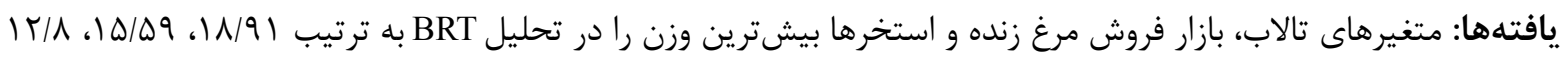
به خود اختصاص دادند. همجّنين، از نظر زمانى ماه بهمن بيشترين ميزان شيوع را در بين r ماه سرد سال داشته است. نتيجه گَيرى: اين بيمارى در نواحى اطراف تالابها و استخرها، نزديكى بازارهاى فروش مرغ زنده مشاهده شده است. بنابراين اداره كل داميزشكى بهعنوان نهاد نظارتى و سياستحذار و توليدكنندگان و فروشندگان مرغ بهعنوان عوامل اجرايى مىتوانند نقش بسيار مهمى در يايش، كنترل و جلو گيرى از شيوع اين بيمارى ايفاء نمايند. وازههاى كليدى: آنفلوانزاى يرندگان، تحليل مكانى، رگرسيون تقويت شده، رگرسيون وزندار جغرافيايى

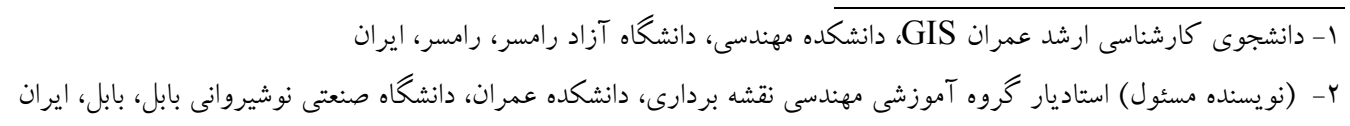

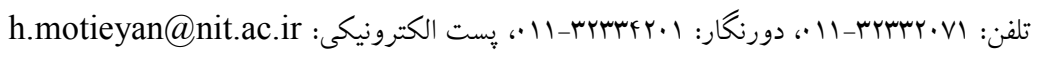


استان و كل كشور نمايش مى داد [ع]. Pandit و همكاران سال

IV · IV، در تحقيقى به اين نتايج رسيدند كه كاهش تماس بين يرندًان وحشى و مرغهاى خانكى و حذف سريع يرندكان خانكى آلوده، باعث كاهش احتمال ابتلاء به بيمارى مىشود

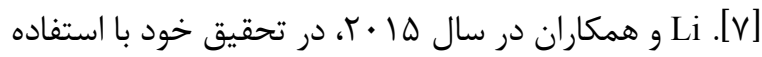
از روش رگرسيون لجستيك جند متغيره، به مشخص كردن الكوهاى مكانى و زمانى آنفلوانزاى تحت تيب H5N1 و شناسايى عوامل مؤثر بر شيوع آن در يرندگان جين پرداختند

اكثر تحقيقات انجام شده در اين زمينه به صورت كيفى و توصيفى بودهاند به اين صورت كه با بررسى مناطقى كه بيش ترين آمار بيمارى را داشتداند سعى در تشخيص عوامل مهامم بيمارى را داشتهاند بدون اينكه اهميت هر يك از آنها شناسايى شود يا تأثير آنها در خستره جغرافيايى منطقه بررسى شود. از طرف ديكر در اندك تحقيقات كمى انجام شده نيز، حساسيت مدلها به تغييرات جغرافيايى محدوده مورد مطالعه بررسى نشده و در تحليل خود اين مسئله را در نظر نَرفتند [r-r-r]. لذا هدف از اين تحقيق، مدل سازى شيوع بيمارى آنفلوآنزاى فوق حاد يرندكان با تلفيقى از قابليتهاى سيستم اطلاعات مكانى و علوم دادهكاوى (Data mining) است تا بتواند به تصميمَيران در خصوص اتخاذ تصميمات

$$
\text { لازم درمورد اين بيمارى كمك نمايند. }
$$

مطالعه حاضر از نوع تحليلى-اكولوزيكى بوده كه محدوده مطالعاتى آن استان گَيلان و سال مطالعه ه9 1 میىباشد. استان گَيلان، يكى از استانهاى شمالى كشور بالغ بر أ أهزار كيلومتر مربع مساحت دارد. در ميان رشته كوههاى البرز و
بيمارى آنفلوانزاى فوق حاد طيور ( Highly Pathogenic يكى از بيمارىهاى مهم تنفسى و Avian Influenza; HPAI واگيردار طيور است كه داراى قدرت انتشار سريع مىباشد [1]. شيوع بيمارىهاى همه گير در جامعه، ذاتاً يك فرآيند زمانى و مكانى است. مدلسازى گسترش و انتقال ناگمهانى اين بيمارىها نيازمند درك بهترى از رفتارهاى يوياى آنها است تا بتوان با اتخاذ صحيح رفتارهاى يِيش گيرانه براى جلوگيرى از عواقب شديد بيمارى اقدام نمود [r]. سيستم اطلاعات مكانى (Geographic Information System; GIS) در واقع مى تواند زمينهاى فراهم نمايد كه اطلاعات توصيفى -مكانى به دست آمده از منابع مختلف، بلهورت كارآمد ذخيره كردند تا بتوان از آنها در بازيابى، تحليل و ارائه مكانى آنها بهصورت نقشههاى موضوعى استفاده نمود. تهيه نقشه بيمارىها مىتواند به محققين كمك نمايد تا عوامل مؤثر و دخيل در بيمارى را تشخيص داده و طرح مناسبى را براى كاهش آن عوامل و يا حذف آنها طراحى نمايند [ب]. در اين زمينه تحقيقاتى در ايران و جهان انجام يذيرفته است. Fallah Mehrabadi و همكاران، بهصورت توصيفى و به روش مقطعى، از مرداد تا مهرماه سال ها لـ ب به بررسى بيمارى آنفلوانزا فوق حاد يرندَان يرداختند. نتايج نشان داد كه شيوع بالاى آنفلوانزاى H9N2 در طيور بومى روستايى در اين طرح نشان دهنده بومى شدن اين بيمارى در آنها مىباشد [Q- [F].

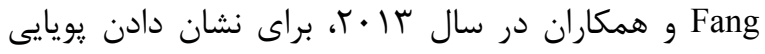
A عسترش عفونتهاى انسانى با ويروس جديد آنفلوانزاى نوع (H7N9) توزيع مناطق آسيبديده و منحنىهاى إييدمى را براى سه 
انزلى، صومعه سرا و شفت بوده است. در ادامه، بين سالهاى

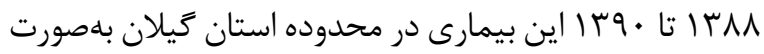

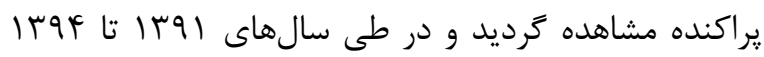
هيج كانون بيمارى گزارش نشد. اما در سال هوَ ا به خصوص در ماههاى آذر، دى و بهمن بيشترين ميزان شيوع در طى سنوات كذاشته كرديد. مناطق آلوده به بيمارى در سال هوبا در روستاهاى منگوده رشت، كيساورزل لاكان، استلك لشت نشاء، مرزدشت خمام، جاده سنكر رُشت شركت نفت و روستاى جيريورد مشاهده شد. بنابراين در اين تحقيق تصميم گرفته شد تا روشى براى مدل سازى بيمارى در اين سه ماه ارائه كردد. روش ارائه شده در اين تحقيق بهصورتى است كه ابتدا با مطالعه تحقيقات كذشته عوامل مؤثر در بيمارى تشخيص داده شد. همرجنين با حضور در مناطقى كه وقوع بيمارى در آن مشاهده شده است، عوامل فوق تكميل گرديد. سيس اين مجموعه عوامل با مصاحبه با يزشكان و داميزشكان در استان تكميل و نهايى شد كه عبارتاند از: تالابها، بازار فروش مرغ زنده، استخرها و درياجهها، دما، جمعيت بخش، جهت باد، كشتار گاه، رطوبت، بارش، تراكم مرغ، ارتفاع از سطح متوسط آبهاى آزاد، راهها، مكان مرغدارىها، نوع يوشش اراضى (مرتع، باير، جنكًل و غيره)، رودخانه، جهت شيب، مقدار شيب. از آنجا كه تمامى اين عوامل به نوعى مكانى هستند سعى ريى شده كه لايههاى آنها در GIS ايجاد كردند. البته براى ايجاد برخى از عوامل، تحليلهاى مكانى نيز لازم بود. بهعنوان مثال عامل دما بلهورت نقطهاى در ايستخاههاى هواشناسى

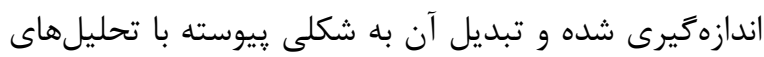
درونيابى مكانى امرى اجتناب نايذير است. بعد از آمادهسازى لئ
تالش در شمال ايران جاى گرفته و حدود 9/• درصد از مساحت كل كشور را در برگرفته است. اين استان در عب درجه و Mr دقيقه تا ب ب درجه و rV دقيقه عرض شمالى و

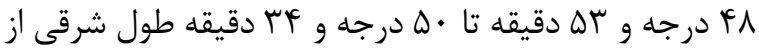
نصفالنهار قرار گرفته است. بر اساس آخرين تقسيمات كشورى، در زمان اجراى سرشمارى نفوس و مسكن هوسا

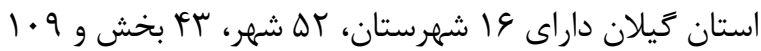
دهستان است و r Y T آبادى بوده است [9]. نمايى از محدوده مطالعاتى يزوهش در شكل ا نشان داده شده است.

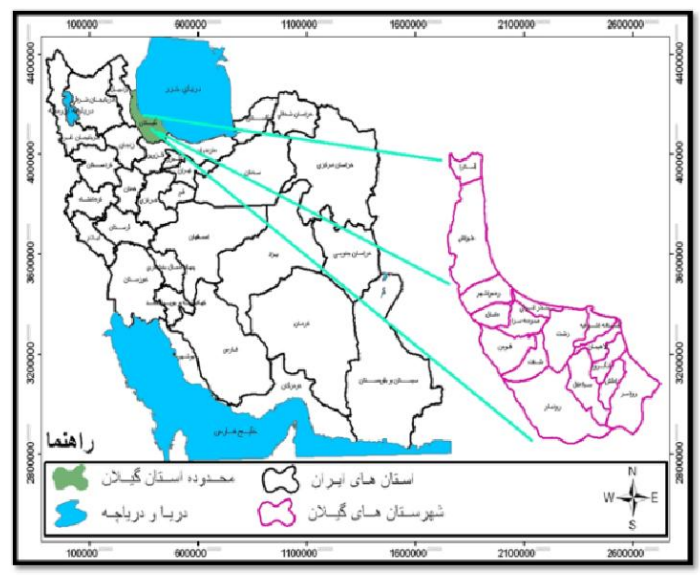

شكل / - مححلوده مطالعاتى (يهنه /ستان كميلان) در نقشه /يران هر ساله با شروع فصل مهاجرت، بسيارى از يرندكان كه حامل ويروس خطرناك آنفلوانزاى فوق حاد هستند در مناطق مختلفى از جمله تالابها، رودخانهها، آبخيرها و جلگههاى كشور سكنى مى ززينند و از طرق مختلف موجب آلودىى محيط اطراف خود به اين ويروس خطرناك مى به كَارش مربوط به وقوع آنفلوانزاى فوق حاد يرندَان مديريت دفتر بهداشت طيور و زنبور عسل اداره كل داميزشكى استان

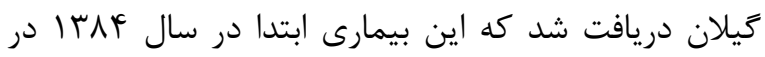

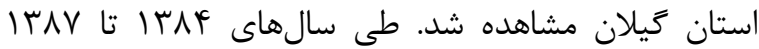
حدود • ^ درصد مشاهدات بيمارى در شهرهاى رشت، بندر 
• • ع مدلسازى شيوع بيمارى آنفلوانزاى فوق حاد برندگان در استان گيلان ...

مىيردازند، از روش بيش برنده مرحلهاى (Stage-wise) تجزيه و تحليل و برازش بين متغيرها و آمار نايارامترى استفاده

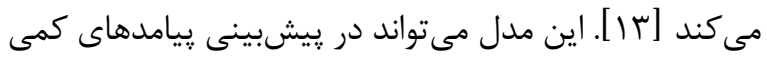
(درخت ركرسيونى) يا طبقه بندى شده (درخت طبقهبندى)

$$
\text { مورد استفاده قرار كيرد [4] أ] }
$$

منحنى (Receiver Operating Characteristic; ROC) عملكرد نسبى مدل را نشان مى دهد. اين منحنى با نمودارى مشخص مىشود كه در آن نسبت پِيكسل هايى كه وقوع يا عدم وقوع بيمارى بلوسيله مدل بلدرستى پيشبينىشده روى محور عمودى (مثبت درست يا Sensitivity) در برابر مقدار مكمل آن يعنى نسبت يِيكسلهايى كه نادرست پِيشبينى شدهاند (مثبت غلط يا Specificity-1) روى محور افقى ترسيم مىشود. AUC مساحت زير منحنى بوده و مدلى كه بيشترين مقدار AUC را دارد، داراى عملكرد نسبى بالاترى است. AUC برابر با ه/• معادل مدل خنثى بوده، مشخصكننده تصادفى بودن مدل است و اگر مقدار AUC به ا نزديك شود موجب افزايش كارآيى مدل مىباشد. در يك مدل خوب سطح زير منحنى بين V/ • تا / ••، در يك مدل عالى سطح زير منحنى 1/ • تا 9/ • و در يك مدل عالى، سطح زير منحنى بيش از 9 •

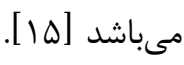

\section{رَرسيون وزندار جغرافيايى}

در مطالعاتى كه داراى بعد مكانىاند و بهعبارت ديكر، متغيرهاى مكانى در آنها دخيل است، سنجش ارتباط بين متغيرها با يك مدل برآوردَر خطى كه داراى ضرائب ثابتى است خطاى برآورد را افزايش مىدهد. بنابراين، در اين نوع مطالعات نياز به مدل برآوردَرى احساس مىشود كه ضرائب آن ثابت نبوده و همراه با متغيرهاى مكانى سيال باشد. در
عوامل و لايههاى مربوطه، اهميت هر يك از آنها از دو طريق

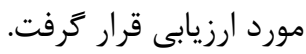
ابتدا به كمك مدل رگرسيون درختى تقويت شده عوامل بدون در (Boosted Regression Tree; BRT) نظرگيرى عامل موقعيت جغرافيايى ارزيابى گرديد. با بررسى تحقيقات انجام شده با مدلهاى مختلف و مدل BRT مىتوان بيان كرد: ا - اين مدل بهطور مستقيم با متغيرهاى ييشبينى كننده مرتبط مىباشد. ץ- درختهاى تصميمخيرى غير پارامتريك بوده و هيج دخالتى از سوى كاربر بر روى آنها صورت نمى گيرد. r- خروجى مدل از دقت بالاى برخوردار است. در نهايت مىتوان بيان كرد به دلايل بيان شده، كار با مدل درختى ييشنهاد مىشود [•l]. سيس با استفاده از مدل ركرسيون وزندار جغرافيائى نقش و (Geographically Weighted Regression; GWR) وزن عامل موقعيت در هر يك از عوامل به دست آمد. در نهايت با ضرب اين دو وزن (وزن مستقل از موقعيت و وزن وابسته به موقعيت) وزن نهايى هر معيار ارزيابى گشت و در نهايت با

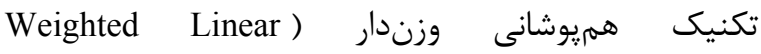
(Combination; WLC ريسكيذيرى بيمارى ايجاد گرديد. البته اين فرآيند براى ماه رايج اين بيمارى يعنى آذر، دى و بهمن مورد ارزيابى قرار كَرفته تا علاوه بر تحليل مكانى، تحليل زمانى نيز در مورد اين

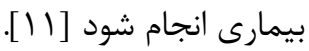
مدل درخت رگرسيونى ييشرفته به عنوان يك تكنيك داده كاوى بر اساس درختهاى طبقهبندى و رگرسيونى همراه با الكَريتم Boosting طراحى شده است [با]]. اين مدل برخلاف الخوريتههايى كه بر اساس ميانگين بهييش بينى 
جغرافيايى نقاط مورد بررسى است. وزنهاى اختصاص داده شده به هر نقطه از تابع وزندهى كه به كرنل معروف است،

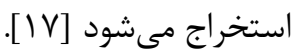

در اين تحقيق از كدنويسى در محيط Matlab نسخه ها • براى تشكيل درخت تصميم و تعيين وزن متغيرهاى كانه و همرجنين از ابزار Modeling Spatial Relationships موجود در Arctoolbox GIS نرمافزار Arc GI0.4 بهمنظور استفاده از آناليز و آزمونهاى آمارى مدل GWR استفاده شده است. نتايج براى تعيين ڤارامترهاى اقليمى مورد نياز در مدلسازى

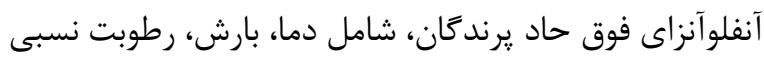
و جهت باد غالب، آمار روزانه r| ايستكاه سينويتيك منطقه از سازمان هواشناسى استان كيلان تهيه شد. متغيرهاى دما، رطوبت و بارش مربوط به ماههاى آذر، دى و بهمن كه در

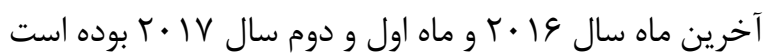
جهت تحليل انتخاب شد. دادههاى مربوطه از سايت سازمان هواشناسى دريافت و با ميانخين گيرى از دما، بارش و رطوبت حداقل و حداكثر در روزهاى ماههاى مطالعاتى، ميانگين دما،

$$
\text { بارش و رطوبت ماهيانه به دست آمد. }
$$

براى تعيين يارامترهاى محيطى از منحنى ميزانهاى

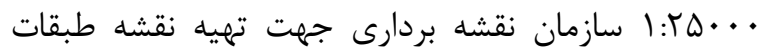
ارتفاع استفاده شد. از نقشه طبقات ارتفاع Digital) Elevation Model; DEM) سازى شد. جهت آماده سازى نقشه رودخانهها، از نقشههاى

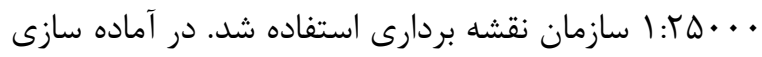
نقشه يوشش گَياهى، از نقشه كاربرى اراضى موجود در اداره منابع طبيعى استفاده شد.
ركرسيون وزندار جغرافيايى، هر داده مشاهداتى به نسبت فاصلهاش از موقعيت مورد برآورد وزن دهى مىشود. به اين معنا كه مشاهدات نزديك به نقطه برآوردى وزن و تأثير بيش ترى در برآورد دارند و مشاهدات دورتر داراى تأثير كمترى هستند و از اين نظر، دقت جغرافيايى كار بالا مىرود. اين مدل ركرسيونى مانند رگرسيون كمترين مربعات معمولى داراى يك متغير وابسته و يك يا جند متغير مستقل است كه مقادير آنها در نقاط با موقعيت مشخص ثبت شده است. رابطه ( (1)،

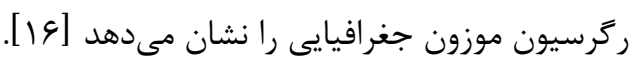

رابطه (1) $y_{-} i(u)=\beta 0 i(u)+\beta 1 i(u) x 1 i+\beta 2 i(u) \times 2 i+\cdots+\beta m i ~(u) x \_m i$ در رابطه (1)، y مقدار متغير وابسته در نقطه (u)، x مقادير مربوط به متغير مستقل در همان نقطه (u)، برآوردَرهاى مدل هستند كه در مدل رگرسيون وزندار جغرافيايى اين ضرايب مشابهت زيادى با مدل ركرسيون وزندار دارند. با اين تفاوت كه در ركرسيون وزندار جغرافيايى وزن مربوط به ضر ايب هر نقطه كاملاً وابسته به موقعيت فضايى آن نقطه و همرجنين موقعيت آن نقطه نسبت به ساير نقاط در منطقه مورد مطالعه است. بهعبارت ديكر، موقعيت هر نقطه در منطقه مورد مطالعه مهممترين عامل تعيين كننده وزن برآوردكرها است كه از طريق حل رابطه (ז)، به دست مى آيند:

$$
\text { رابطه (r) }
$$

$(\mathrm{XT} W(\mathrm{u}) \mathrm{X})(-1) \mathrm{XT} W(\mathrm{u}) \mathrm{y} \beta(\mathrm{u})=$ در رابطه (Y) ماتريس مربعى وزن W(u) ماست كه مقدار وزن تخصيص يافته به آن به موقعيت (u) در منطقه مورد مطالعه وابسته است. XW(u)X ماتريس كوواريانس وزندار مكانى است. Y مقادير مربوط به متغير وابسته در همان نقطه است. (u) ماتريسى است كه قطر اصلى آن وزنهاى (u) 
4AN مدلسازى شيوع بيمارى آنفلوانزاى فوق حاد برندگان در استان گيلان ...

كشتار Fاهها و مرغدارىها، اطلاعات مكانى 1 كشتار Fاه و r ب

واحد مرغدارى در سيستم مختصات جغرافيايى، از اداره كل

داميزشكى استان كَيلان دريافت و به سيستم مختصات

UTM (Universal Transverse Mercator)

آنها آماده شد. در انتها نيز، جهت تهيه نقشه تراكم جمعيت،

اطلاعات جمعيتى بخشهاى استان كيلان از سايت مركز آمار

به نقشه بخشهاى استان گيلان متصل شد. همرجنين نقشه

مناطق آلوده به بيمارى نيز كه در آن وقوع بيمارى مشاهده

شده است آماده سازى شد. نقشه بازارهاى فروش مرغ زنده كه

در انزلى، صومعهسرا، تولم شهر، حسن رود، سياهكل بود نيز

آماده گرديد. برخى از اين متغيرها در شكل r نشان داده شده
همرجنين براى متغيرهاى انسانساز شامل موقعيت

استخرها، تالابها، راهها، مرغدارىها، كشتار گاهها، تراكم مرغ زنده، تراكم جمعيت و بازارهاى فروش، فرآيند زير صورت

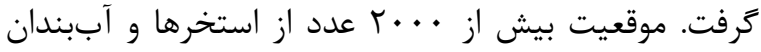
هاى استان گيلان از شركت سهامى آب منطقهاى، دريافت كرديد. با استفاده از نقشههاى دريافتى از اداره كل محيط زيست، مناطق تحت مديريت سازمان محيط زيست تعيين و Google earth طى بازديدهاى ميدانى و استفاده از تصاوير نقشه تالابهاى محدوده مطالعاتى استخراج شد. با استفاده از دادههاى دريافتى از اداره راه و شهرسازى و نقشههاى

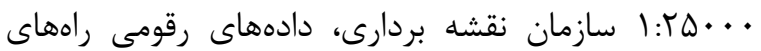
محدوده مطالعاتى آماده سازى شد. جهت تهيه نقشه
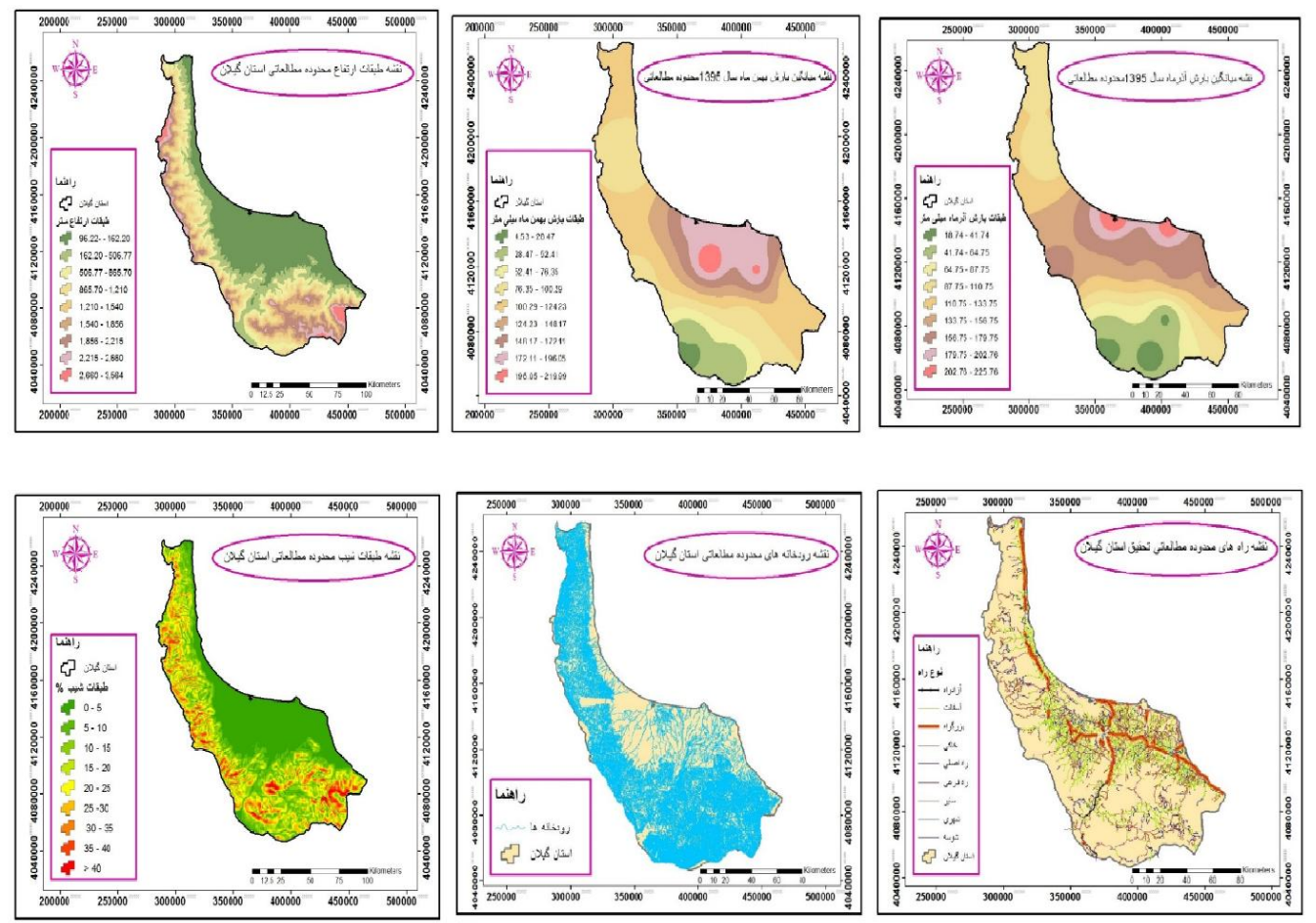

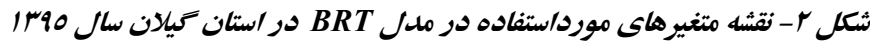




\begin{tabular}{|c|c|c|c|}
\hline \multicolumn{2}{|c|}{ درخت ركرسيون تقويتشده } & \multirow[t]{2}{*}{ متغير } & \multirow[t]{2}{*}{$\hat{3}$} \\
\hline انحراف معيار وزن & ميانگين وزن & & \\
\hline $9 / 11$ & $11 / 91$ & ت تالابها & 1 \\
\hline$\Delta / \Lambda \Gamma$ & $10 / \Delta 9$ & بازار فروش مرغ زنده & t \\
\hline$\varphi / \cdot \Delta$ & $\mid r / A$ & استخرها و درياجهها & r \\
\hline r/gF & $N / G F$ & دما & r \\
\hline 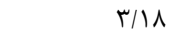 & V/T & جمعيت بخشها & $\Delta$ \\
\hline$r / \cdot r$ & G/TI & جهت باد & 4 \\
\hline r/AV & $\Delta / 9 F$ & كشتار كاه & $\checkmark$ \\
\hline$r / r q$ & $\Delta / \Delta \varphi$ & ر روبت & $\wedge$ \\
\hline$r / r q$ & $\Delta / \cdot \varphi$ & بارش & 9 \\
\hline$r / \cdot 9$ & F/AT & تراكم مرغ & 1. \\
\hline$r / \cdot 1$ & $F / V r$ & ارتفاع & 11 \\
\hline $1 / 99$ & r/9९ & lool & IT \\
\hline $1 / \uparrow a$ & r/q & مرغدارىها & ir \\
\hline $1 / \pi r$ & $r / 4 q$ & كاربرى اراضى & If \\
\hline$\cdot \mid M F$ & $r / V I$ & رودخانه & 10 \\
\hline$\cdot 199$ & $r|9|$ & جهت شيب & 19 \\
\hline$\cdot \operatorname{cr}$ & I/Ar & شيب & IV \\
\hline
\end{tabular}

متغير و • Vرصد دادههاى مناطق آلوده به بيمارى VV (متغير1/) بهعنوان دادههاى آموزشى در مدل BRT معرفى كرديد تاوزن متغيرهاى پيشبينى كننده و انحراف معيار آنها با توجه به دادههاى آموزشى به دست آيد كه در جدول ا(وزنهاى حاصل از مدل BRT در مدل سازى ييشبينى شيوع آنفلوآنزاى فوق حاد يرندًان) مقادير آنها بيان شده است. سِس با استفاده از وزنهاى بلدست آمده و انحراف معيار وزنها، مدل يِيشبينى شيوع آنفلوانزاى حاد يرندگان در ماههاى آذر، دى و بهمن ايجاد شد. در مرحله بعد، متغيرها وارد مدل GWR شده و وزن هر يك با در نظرگيرى تغييرات جغرافيايى محاسبه گرديدند. شكل ب نمونهاى از اين وزنها را بيان مى كند.
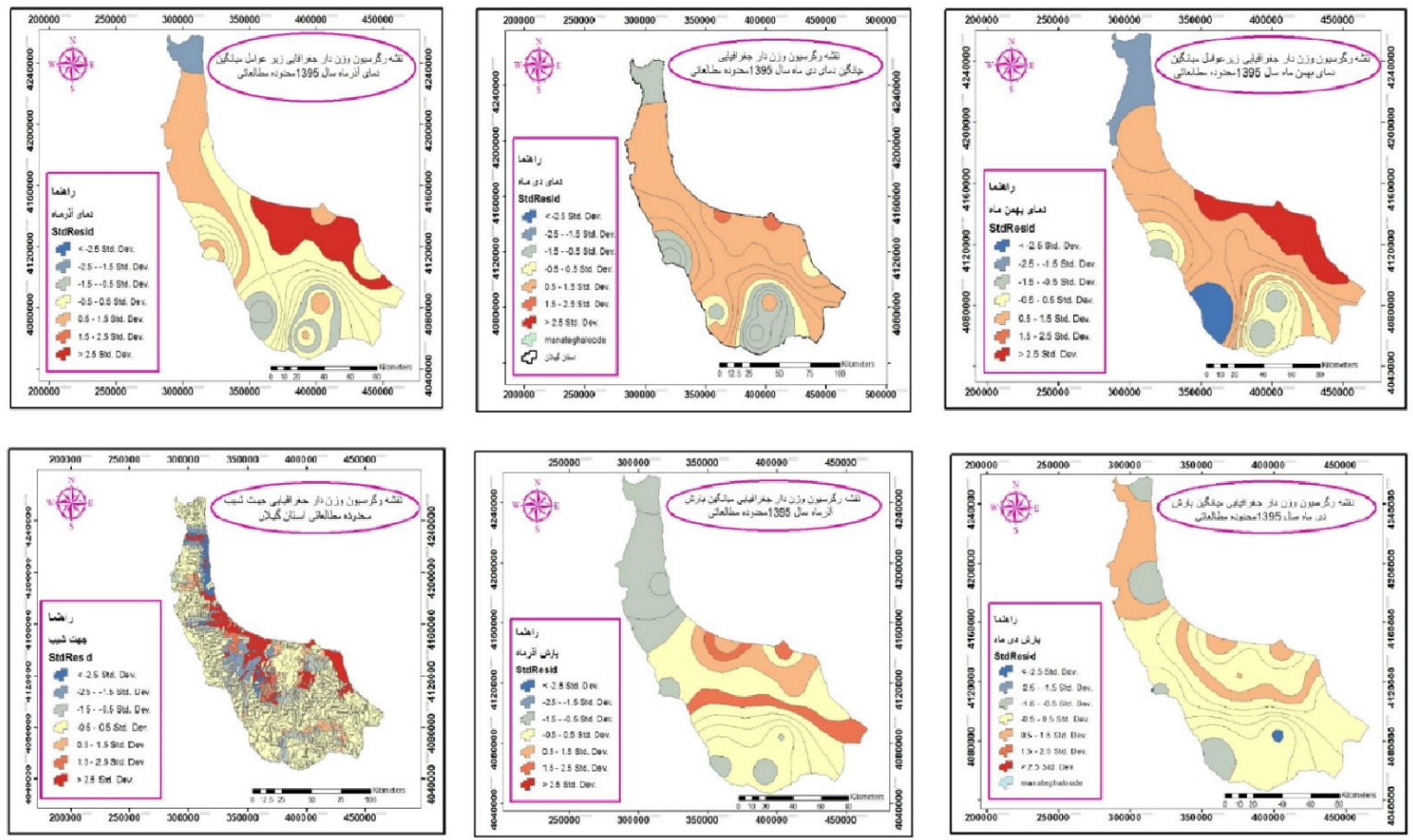

شكل r- نقشه هاى وزنهاى بهدست آملده توسط روش ركرسيون وزندار جغرافيا يیى 
درنهايت وزن بهدست آمده از BRT در لايههاى ركرسيون وزندار) همريوشانى لايهها براى ب ماه آذر، دى و بهمن به

وزندار جغرافيايى ضرب و با روش WLC (تركيب خطى دست آمد كه در شكل أل، نشان داده شده است.
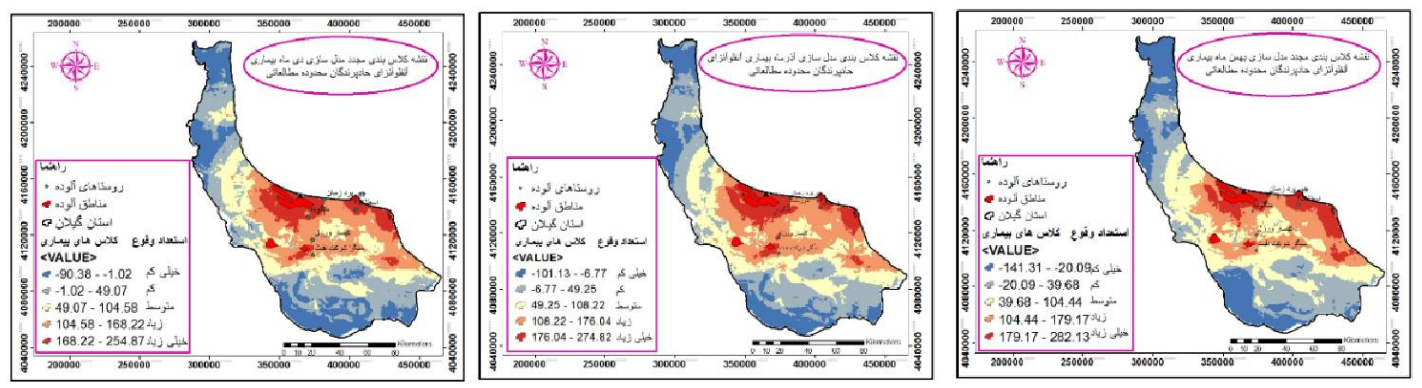

شكل ع- كلاسبندى نقشه مدل سازى آنفلوانزاى حاد يرندكان دو سه ماه آذر، نيى و بهمن با روش BW و BRT

\begin{tabular}{|c|c|c|}
\hline $\mathbf{R}^{2}$ Adjusted & $\mathbf{R}^{2}$ & ن ام متغير \\
\hline . 194 & .199 & جهت باد غالب آذر ماه \\
\hline.$/ 91$ & .195 & جهت شيب \\
\hline - /AV &.$/ 9$ & كشتار كاه \\
\hline •/Ar & $\cdot 119$ & ميانكَين بارش آذر ماه \\
\hline •/AT & - IAV & تالاب \\
\hline - / $A \Delta$ & - /ADT & كاربرى اراضى \\
\hline$\cdot / v 9$ & $\cdot / \wedge \Delta$ & جهت باد غالب دى ماه \\
\hline$\cdot / V^{4}$ & $\cdot / \Lambda F$ & جمعيت بخش \\
\hline - /va & $\cdot / A F$ & ميانكَين بارش دى ماه \\
\hline $.19 \mathrm{~V}$ & $\cdot|\Lambda|$ & ميانكَين بارش بهمن ماه \\
\hline$\cdot / V^{4}$ & $\cdot / 1$ & استخرها و درياجهها \\
\hline - /Va & $\cdot / \vee q$ & مرغدارىها \\
\hline $.19 \mathrm{~V}$ & $\cdot 199$ & راهاol \\
\hline$\cdot \mid \Delta \Delta$ & $\cdot \mid 9 V$ & جهت باد غالب دى ماه \\
\hline$\cdot / \& \Delta$ & . & ميانكَين دماى بهمن ماه \\
\hline$\cdot / \Delta V$ & . & ارتفاع ا \\
\hline - IDT & $\cdot|9|$ & ميانكَين دماى آذر ماه \\
\hline$\cdot / 0$ &.$|9|$ & ميانكَين رطوبت دى ماه \\
\hline$\cdot \mid \Delta \Lambda$ & .19 & رودخانه \\
\hline$\cdot 19$ & .19 & شيب \\
\hline$\cdot / 49$ & $\cdot / \Delta F$ & ميانَين رطوبت بهمن ماه \\
\hline .101 & $\cdot / \Delta r$ & بازار فروش مرغ زنده \\
\hline$\cdot / 4 V$ & $\cdot|4|$ & ميانكَين رطوبت آذر ماه \\
\hline . & • & ميانكَين دماى دى ماه \\
\hline .111 & - RF & تراكم مرغ \\
\hline
\end{tabular}

براى بررسى عملكرد مدل از منحنى ROC استفاده ترديد

كه در شكل ه، نشان داده شده است.

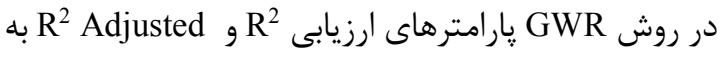

دست آمدند كه در جدول r بيان شده است. مقادير اين

ضرايب از طريق اختلاف بين مقادير مشاهده شده يا واقعى با

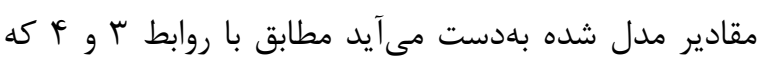
مقادير بالاتر بيانگر اين مىباشد كه جقدر از تغييرات خروجى متأثر از ورودى مربوطه مىتواند باشد. در بين متغيرها، جهت

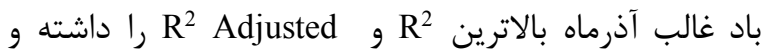
متغيرهاى جهت شيب، كشتار گاه، ميانخين بارش آذرماه و غيره در الويتهاى بعدى قرار دارند. در اين بين متغير تراكم مرغ با كمترين R و R Adjusted به ضعيفترين حالت وقوع بيمارى را توضيح داده است.

رابطه (广)

$$
R^{2}=1-\frac{S S E}{S S T}
$$

(i) (i) (1)

adjusted__ $R^{2}=1-\frac{\left(1-R^{2}\right)(1-N)}{N-P-1}$

كه در روابط فوق SSE بيانگر مجموع توان دوم تفاضل مشاهده واقعى و مقادير مدل، SST ميانگين مقادير مشاهده شده، N تعداد مشاهدات و P تعداد متغيرهاى يِيشبينى كننده است

جدول r - مقادير مختلف 
در سالهاى اخير نكَرانى راجع به بيمارى آنفلوانزاى فوق حاد يرندكان به دليل اثرات زيانبار اقتصادى آن بر صنعت طيور، بهداشت عمومى جامعه و تجارت بينالمللى و همرجنين نكرانى از احتمال انتقال بيمارى به انسان، افزايش يافته است. هر ساله با مهاجرت يرندگان مهاجر بين كشورهاى مختلف شاهد بروز اين بيمارى در كشورهايى كه اين يرندًان به آن

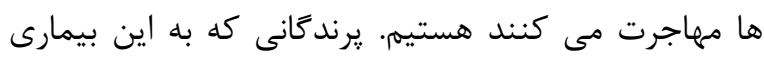
مبتلا مى گردند هركز بهبود يِيدا نمى كنند، يا مىميرند و يا بايد معدوم شوند. از اين رو مطالعه و بررسى مدل شيوع اين بيمارى به منظور جلوگيرى از هرگونه خسارات ناشى از آن اهميت ييدا مى كند. در اين يزوهش، با ارائه يك مدل تحليلى مكانى نقش عوامل اقليمى، محيطى و انسانى در مدلسازى آنفلوانزاى حاد يرندگان با مدلهاى BRT و GWR مورد بررسى قرار گرفت. با بررسى كليه متغيرها، شامل متغيرهاى عوامل اقليمى (ميانگَين بارش، ميانگَين دما، جهت باد غالب و رطوبت)، متغيرهاى عوامل محيطى (يوشش گياهى، ارتفاع، شيب، جهت شيب، فاصله از رودخانه) و متغيرهاى انسانى (تالابها، استخرها و آببندان ها، راهها، تراكم مرغ، جمعيت بخش، بازار فروش مرغ زنده، كشتار گاه، مرغدارىها) ابتدا وزنها در مدل BRT بهصورت زير محاسبه كرديد. نتايج يزوهش حاضر نشان داد كه از بين متغيرهاى مورد بررسى، وضعيت فاصله از تالابهاى منطقه بلهعنوان يك عامل مخاطره آميز بوده و وزن آن در مدل BRT بيشترين مقدار با عدد |N/9 بوده است و ميزان شيوع در روستاهايى كه در نزديك تالابها قرار دارند بهطور بسيار معنىدارى بيشتر از روستاهايى است كه دور از تالاب قرار دارند. همرجنين در متغيرهاى مورد بررسى عامل شيب با وزن 1/Ar داراى كم

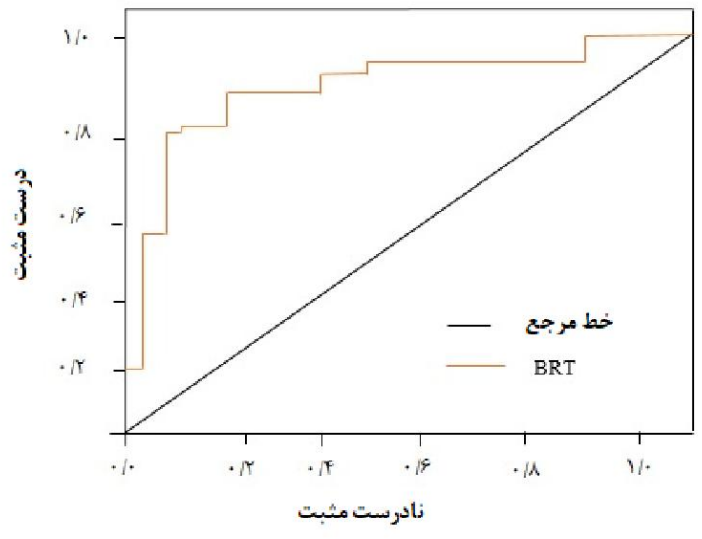

شكل ه- منحنى ROC براي مدل BRT در مدل سازى آنفلوانزاع فوق حاد يزند حان با توجه به نمودار شكل ه و خلاصه نتايج نمودار ROC كه در جدول ץ بيان شده است، مساحت زيرمنحنى، 1/|• كه نزديك به عدد ا است كه حاكى از كارآيى مدل مىباشد. همرجنين سطح معنىدارى تقريباً صفر بيانكر اين است كه فرضيه اين كه مدل به صورت تصادفى عمل مىكند و كار آيى ندارد با احتمال صفر درصد مىباشد. بنابراين اين احتمال و مساحت زير منحنى قابليت بالاى مدل BRT را در تشخيص مناطق وقوع بيمارى تأييد مى كند. البته مقادير انحراف معيار و اختلاف كران بالا و پايين منحنى بيانگر اين مىباشد كه مدل داراى قطعيت بسيار بالا نبوده و كمى داراى حساسيت مىباشد. بنابراين جهت افزايش قطعيت مدل تشخيص از روشى GWR استفاده كرديد. جدول r- مقادير خروجى آزمون ROC دو مدل BRT

\begin{tabular}{|c|c|c|c|c|}
\hline \multicolumn{2}{|c|}{ سطح اطمينان 90 درصد } & \multirow[t]{2}{*}{ معنادارى } & \multirow[t]{2}{*}{ خطاى انحراف } & \multirow{2}{*}{$\begin{array}{l}\text { زيرمنحنى } \\
\text { ROC }\end{array}$} \\
\hline باند بالا & باند بايين & & & \\
\hline$\cdot / 91$ & . 194 & $<\cdot / \cdot 1$ & $\cdot / 49$ & $\cdot 1199$ \\
\hline
\end{tabular}


ع \& مدلسازى شيوع بيمارى آنفلوانزاى فوق حاد يرندگان در استان گيلان ...

امر با تحقيقات انجام شده در خصوص افزايش رشد ويروس آنفلوانزا در محيطهاى مرطوب مطابقت دارد. نتايج اين يزوهش مشابه بررسى انجام گرفته توسط Hadipour و همكاران در بروز اين بيمارى روى اردكها مىباشد كه بيش ترين ميزان شيوع را شمال كشور به دست آوردند كه علت آن را وجود درياجهها و تالابها عنوان كردهاند [V IV]. همرجنين در مطالعه انجام گرفته توسط Madsen و همكارانش، مواجهه با يرندًان آبزى، عدم كنترل آفات و موقعيت جغرافيايى در

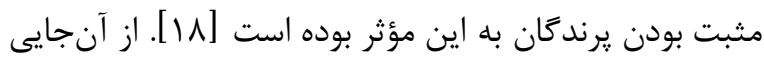
كه بر اساس اين تحقيق، جهت باد جزء عوامل تأثيرگذار در شيوع اين بيمارى تعيين شده است و با توجه به همجوارى استان كَيلان با استانهاى مازندران، كَلستان و كشورهايى كه پذيراى يرندكان مهاجر، ضرورت شناسايى و تهيه متغيرهاى معرفى شده در محدودههاى جغرافيائى همسايه بيش از بيش اهميت پِيدا مىكند تا از طريق يك همكارى مشترى بينالمللى امكان تهيه مدل يوياو ييوسته از اين بيمارى فراهم كردد [9 19]. لازم به ذكر است كه در مطالعهاى كه در ارويا در ارتباط با عوامل خطر مرتبط با رخداد آنفلوانزا با استفاده از مدل ركرسيون لجستيك انجام گرفت، افزايش شاخص يوشش Fياهى نرمال شد (Normalized Difference Vegetation (Index; NDVI مارس، ارتفاع يايين، افزايش دماى حداقلى در زانويه و كاهش بارش در زانويه ازجمله عوامل خطر مرتبط با اين بيمارى در يرند كان مهاجر بودند. همرجنين نقشههاى خطر نشان مىدهند كه اين بيمارى در ارتباط با در دسترس بودن منابع غذايى، افزايش دما و كاهش بارندگى است. نتايج مطالعه انجام گرفته در تركيه نشان داد كه نزديكى به شبكهاى ارتباطى (راههاى
ترين تأثير در مدل BRT بوده است. نتايج و وزنهاى مدل BRT در اين يروهش، با نتايج تحقيقات [ع]، كه مدلسازى شيوع و خطر ابتلاء به آنفلوانزاى يرندكان(A(H7N9 را در جين را با مدل BRT انجام دادند مشابهت زيادى داشته است و نتايج اين تحقيق را تأييد مى كند. در مرحله بعد متغيرها، با روش GWR ارزش خذارى شد و ارتباط بين متغيرهاى مستقل و متغير وابسته وقوع بيمارى سنجيده مىشود. در مقايسه مساحت كلاسهاى بيمارى در ماههاى آذر، دى، بهمن در سال هوب |، نيز نتايجى حاصل شد. در ماه آذر، بيش ترين مساحت، مربوط به كلاس كم با مساحت | و كمترين مساحت مربوط به كلاس خيلى زياد با مساحت 9/DV درصد به دست آمد. در ماه دى، بيشترين مساحت مربوط به كلاس كم با مساحت س س/IT و كلاس خيلى زياد با مساحت ه/9/ درصد پايينترين مساحت را در اين ماه به خود اختصاص داده است و در نهايت در بررسى كلاسهاى مساحت بيمارى بهمنماه، كلاس كم با مساحت ه/Q Q ب درصد بالاترين مساحت را به خود اختصاص داده است. در اين ماه كلاس مساحت خيلى زياد پايينترين اولويت را با مساحت سم/ه درصد به خود اختصاص داده است. بنابر اين بيشترين مساحت كلاس خيلى زياد در دى ماه اتفاق افتاده است. مقايسه مناطق وقوع بيمارى حاصل از مدل سازى با مناطق وقوع بيمارى در سال هوبا، نشان داد كه اين دو منطقه اشتراكات بسيار زيادى با يكديكر دارند. به اين ترتيب كه كلاس احتمال وقوع زياد مدل ارائه شده، در نزديكى مناطق وقوع بيمارى در سال ه9 بوده است. مناطق وقوع بيمارى در مدل ارائه شده در نزديكى تالابها و درياجهها بوده است. وقوع بيمارى در مناطق مرطوبتر بيشتر ديده شده است كه اين 
مذكور بوده كه مدل سازى تحليلى-مكانى آن مىتواند در تصميه گيرىها كمك كند. بنابراين، در اين تحقيق با بررسى يارامترهاى مؤثر در شيوع اين بيمارى، مدلى ارائه گرديد تا اهميت هر يارامتر مورد ارزيابى گرددد. اين مدل در ب ماه سرد سال كه بيشتر در اين بيمارى شايع است مورد ارزيابى گرفت و ضمن تشخيص يارامترهاى مهم در شيوع اين بيمارى، خطر شيوع بيمارى در شرايط مكانى-زمانى نيز در منطقه گيلان

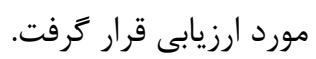

بنابر نتايج يزوهش، مثبت بودن وقوع بيمارى، در برخى شهرستانها مىتواند زنغ خطرى براى صنعت طيور كشور باشد. در اين راستا استفاده از GIS يكى از راههاى دادن هشدارهاى سلامتى به مردم در معرض خطر است. با مشخص نمودن مكان انتشار بيمارى، مردم نسبت به محيط پِيرامون خودآكاهتر شده، مسائل ييش گيرى را بهتر درك خواهند نمود. همرجنين با مشخص شدن مراكز بيمارى، هزينهها و مصارف بهداشتى تعديل مىيابند جرا كه مردم مناطق مستعد بيمارى، عوامل خطر را درى نموده، درصدد يِيشيرى برمىآيند. زمانى كه نقشه شيوع و توزيع فضايى بيمارىها كه علتهاى متفاوت دارند ترسيم مىشود، تفاوتهاى حائز اهميتى از يك نقطه به نقطه ديخر مشاهده مىشود كه در علتيابى و درمان كمك شايان توجهى را به مسئولين مىنمايد. با عنايت به مباحث فوق، مىتوان بيان داشت امروزه استفاده مؤثر و استخراج دادهاى ينهان از انبوه دادهها در مديريت سلامت و بهداشت و درمان، توسط مديران بلعنوان يك هدف عمده جهت بهبود وضعيت موجود تلقى مىشود و استفاده از تكنيكهاى دادهاوى مىتواند بلعنوان ابزار عملياتى در
اصلى) و شهرها در گسترش بيمارى نقش دارند كه علت آن را تمايل احداث مزارع نزديك شهرها و راههاى ارتباطى براى دسترسى به بازارهاى فروش بيان مى كنند [ • []. هم:جنين در اين مطالعه، سرد شدن هوا را در گسترش بيمارى مؤثر دانستند. در مطالعه ديكرى كه با استفاده از مدلهاى انجام گرفت، طغيان آنفلوانزا با تجارت، بازارهاى فروش

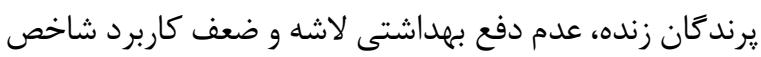

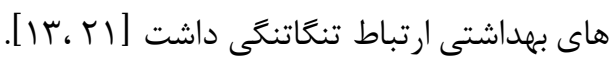
تمامى نتايج حاصل از تحقيقات ديكران با خروجى تحقيق فعلى همخوانى دارد. متأسفانه دادههاى محل وقوع اين بيمارى در استان گيلان طى سالهاى گذشته بهصورت سيستماتيك و منظم جمع آورى نكرديده است، از اين رو راستى آزمايى سيى مدل تهيه شده در سال هوسا در مقايسه با شيوع بيمارى در سالهاى كذشته با محدوديت مواجه است. در اين راستا ييشنهادهايى جهت بهبود تحقيقات آتى ارائه مى • يايش مستمر طيور روستايى، بازارهاى فروش يرندَان و يرندكان آبزى براى بررسى وضعيت آنفلوانزا • تشريك مساعى بين علوم جغرافيا و بزشكى در جامعه نياز است تا برنامهريزى و به كارگيرى يك سيستم قابل قبول

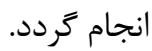
• استفاده از ساير روشها مانند شبكه عصبى و ماشين بردار رشتيبان و مقايسه آن با نتايج تحقيق حاضر.

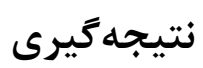

با توجه به افزايش جمعيت، سلامت جامعه يكى از مسائل مهم براى هر جامعه است. يكى از موارد مهمم در زمينه تهديد سلامت عمومى بيمارىهاى واگيردار است. در اين ميان، بيمارى آنفلوآنزاى فوق حاد يرندگان يكى از بيمارىهاى 
AM مدلسازى شيوع بيمارى آنفلوانزاى فوق حاد برندگان در استان گيلان ...

به اين وسيله نويسندكان مقاله مراتب تقدير و تشكر خود را از

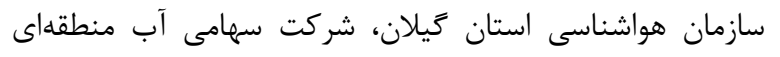

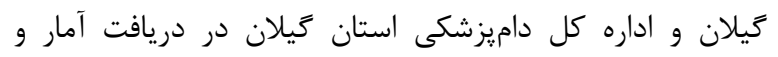
اطلاعات دقيق ابراز مىنمايند.

$$
\begin{aligned}
& \text { شناسايى مناطق آلوده و ارزيابى و نظارت بلمنظور } \\
& \text { تصميم گيرىهاى علمى برنامه ريزان و مديران مفيد واقع شود. }
\end{aligned}
$$

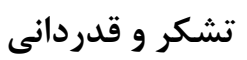

\section{References}

[1] Hablolvarid MH. Influenza disease: a review on epidemiological studies, pathogenesis and genetically alteration upon the avian influenza viruses circulating in Iran, on the field of veterinary medicine and medicine in two recent decades. Veterinary Researches Biological Products (PAJOUHESH-VASAZANDEGI) 2016; 29(1): 17-31. [Farsi]

[2] Tabasi M, Al-Sheikh AA. Modeling the spatial expansion of epidemic diseases using simulation of the base factor (Case study: seasonal flu). Scientific-Research Journal of Geomatics Science and Technology 2016; 6(4): 75-86. [Farsi]
[3 ]Khakshour Z, Arabi M, Hossein Ali F. Spatialtemporal modeling of malaria outbreak, 2nd National Conference on Spatial Information Technology, K. N. Toosi University of Technology, Faculty of Geodesy and Gematics Engineering, January 29, 2016. [Farsi]

[4] Fallah Mehrabadi MH, Bahonar AR, Zeinolabedin Tehrani F, Vasifi Marandi M, Sadrzadeh A, Ghafouri SA, et al. Seroepidemiology of Avian Influenza (H9N2) in Rural Domestic Poultry of Iran. Iranian Journal of Epidemiology 2015; 10 (4): 1-9. [Farsi]. 
[5] Fallah Mehrabadi MH, Bahonar AR, Sadrzadeh, A, Vasifi Marandi M, Zeinolabedin Tehrani F. Investigation of Spatial Patterns and Analysis of Avian Influenza Clusters (H9N2) in Native Villages of Country Villages in 2013 and 2014. Journal Veterinary Research and Construction 2016; 114(1). [Farsi]

[6] Fang LQ, Li XL, Liu K, Li YJ, Yao HW, Liang S, et al. Mapping Spread and Risk of Avian Influenza A (H7N9) in China. Sci Rep 2013; $3(2722)$.

[7] Pandit P, Bunn D, Pande S, Aly S. Modeling highly pathogenic avian influenza transmission in wild birds and poultry in West Bengal, India. Sci. Rep 2017; 3(2175).

[8] Li XL, Liu K, Yao HW, Sun Y, Chen WJ, Sun RX, et al. Pathogenic Avian Influenza H5N1 in Mainland China. Int J Environ Res Public Health 2015; 12(5), 5026-45.

[9] Statistical Yearbook. General Census of Population and Housing 2016. [Farsi]
[10] Shataee S, Kalbi S, Fallah A, Pelz D. Forest attribute imputation using machine-learning methods and ASTER data: comparison of kNN, SVR and random forest regression algorithms. Int. J. Remote Sens 2012; 33(19): 6254-80.

[11] Elith J, Leathwick JR, Hastie T. A working guide to boosted regression trees. J. Anim. Ecol 2008; 77(4): 802-13.

[12] Bui DT, Tuan T., Klempe H, Pradhan B, Revhaug I. Spatial prediction models for shallow landslide hazards: a comparative assessment of the efficacy of support vector machines, artificial neural networks, kernel logistic regression, and logistic model tree. Landslides 2016; 13(1): 361-78.

[13] Naghibi SA, Pourghasemi H, Dixon B. GIS based groundwater potential mapping using boosted regression tree, classification and regression tree, and random forest machine 
•و و مدلسازى شيوع بيمارى آنفلوانزاى فوق حاد برندگان در استان گيلان ...

learning models in Iran. Environ Monti Assess

2016; 188(44): 1-27.

[14] Yang RM, Zhang GL, Liu F, Lu YY, Yang M, Yang F, et al. Comparison of boosted regression tree and random forest models for mapping topsoil organic carbon concentration in an alpine ecosystem. Ecol Indic 2016; 60(1): $870-8$

[15] Cranjadi A, Pourghasemi HR, Landslide Sensitivity Assessments Using Data Mining Models, Case Study: Chehelchai watershed. Watershed Engineering and Management 2021; 11(1): 28-42. [Farsi]

[16] Ahangar Kani M, Farnaghi M, Shirzadi MR. Time spatial prediction of high-risk areas of leptospirosis using geographical and latent regression methods and multilayered perceptron neural network, Journal of Geomatics Science and Technology 2016; 6(2): 79-98. [Farsi]
[17] Hadipour MM, Golchin P. Serosurvey of H9N2 avian influenza virus during respiratory disease outbreaks in broiler flocks in Dezful, southern Iran. Bulg J Vet Med 2011; 14(1): 6265.

[18] Madsen JM, Zimmermann NG, Timmons J, Tablante NL. Avian influenza seroprevalence and biosecurity risk factors in Maryland backyard poultry: A cross-sectional study. PLoSOne 2013; 8(1): 1-8.

[19] Pourtaghi ZS, Pourghasemi HR, Aretano R, Semeraro T. Investigation of general indicators influencing on forest fire and its susceptibility modeling using different data mining techniques. Ecol Indic 2016; 64 (1): 72-84.

[20] Wang SY, Skidmore TAK, De Boer WF, Li L, Prins HHT. Environmental Factors Influencing the Spread of The Highly Pathogenic Avian Influenza H5N1 Virus In Wild Birds In Europe. Ecol Soc 2010. 15(3): 26. 
[21] Naghibi SA, Pourghasemi HR. A comparative assessment between three machine learning models and their performance comparison by bivariate and multivariate statistical methods in groundwater potential mapping. Water Resour Manage 2015; 29(14): 5217-36. 
ك99 مدلسازى شيوع بيمارى آنفلو انزاى فوق حاد يرندگان در استان گيلان ...

\title{
Modeling the Prevalence of Avian Influenza in Guilan Province Using Data Mining Models and Spatial Information System in 2016: An Ecological Study
}

\author{
S. M. Hashemi Foumani ${ }^{1}, \underline{\text { H. Motieyan }}{ }^{2}$ \\ Received: 08/06/2020 Sent for Revision: 23/06/2020 Received Revised Manuscript: 29/07/2020 Accepted: 01/08/2020 \\ Background and Objectives: Infection of birds to Highly Pathogenic Avian Influenza (HPAI) and their extinction \\ impose heavily losses on the livestock and poultry industry along with public health. Nowadays, due to the volume \\ and variety of data, the need of using location-based technologies and data mining sciences has become inevitable. \\ This study aims to model the prevalence of avian influenza, using the capabilities of spatial analyses.
}

Materials and Methods: In this analytical-ecological study, the year 2016 is selected as the target year to prepare 17 variables (climate, environment, and man-made) and their spatial layers in Guilan province because of the high prevalence of the disease in this year. The weights of the variables were computed through combination of Boosted Regression Trees (BRT) analysis and Geographically Weighted Regression (GWR), and then prevalence of the disease was prepared and evaluated by the Receiver Operating Characteristic (ROC) curve.

Results: The variables of wetlands, live poultry markets, and pools have the highest weights according to BRT analysis, with $18.91,15.59$, and 12.8 percent, respectively. Also, in terms of time, the month of February has the highest prevalence among the three cold months of the year.

Conclusion: The disease has been observed in the areas around wetlands, pools, and live poultry markets. Therefore, the General Veterinary Administration, as a regulatory and policy-making body, and poultry producers and sellers as executive agents can play a significant role in monitoring, controlling, and preventing the spread of the disease.

Key words: Avian influenza, Spatial analysis, Boosted regression, Geographically weighted regression

Funding: This study did not have any funds.

Conflict of interest: None declared.

Ethical approval: The Ethics Committee of Babol Noshirvani University of Technology approved the study.

How to cite this article: Hashemi Foumani S M, Motieyan H. Modeling the Prevalence of Avian Influenza in Guilan Province Using Data Mining Models and Spatial Information System in 2016: An Ecological Study. J Rafsanjan Univ Med Sci 2020; 19 (7): 677-92. [Farsi]

1- MSc Student of GIS, Engineering Faculty, Ramsar Azad University, Ramsar, Iran, ORCID: 0000-0002-0452-1706

2- Assistant Prof., Dept. of Geomatics, Faculty of Civil Engineering, Bobal Noshirvani University of Technology, Babol, Iran, ORCID: 00000002-3733-7147

(Corresponding Author) Tel: (011) 32332071, Fax: (011) 32334201,E-mail: h.motieyan@nit.ac.ir

دوره 19، شماره V، سال

مجله دانشگاه علوم يزشكى رفسنجان 